BIBLIOTIKA : Jurnal Kajian Perpustakaan dan Informasi

Volume 2 Nomor 1, 2018

Journal homepage : http://journal2.um.ac.id/index.php/bibliotika

\title{
PERILAKU PENELUSURAN INFORMASI MAHASISWA DALAM PEMANFAATAN MEDIA VIDEO ONLINE DENGAN PENDEKATAN USES AND GRATIFICATION
}

\author{
Fakhriza Palaivi, Ida Lestari, Taufiq Kurniawan* \\ Universitas Negeri Malang, Indonesia
}

\begin{tabular}{l} 
A R T I C L E I N F \\
\hline Keyword: \\
Perilaku Penelusuran \\
Informasi, \\
Mahasiswa, \\
Uses and Gratificatiom, \\
Media Video Online
\end{tabular}

\begin{abstract}
A B S T R A C T
Penelitian ini bertujuan untuk mendeskripsikan perilaku penelusuran informasi melalui media video online oleh mahasiswa Fakultas Sastra Universitas Negeri Malang dan kebutuhan informasi mahasiswa Fakultas Sastra Universitas Negeri Malang dengan pendekatan Uses and Gratification melalui media video online. Penelitian ini menggunakan pendekatan kuantitatif berjenis studi deskriptif. Data penelitian berupa hasil analisis mengenai perilaku penelusuran informasi melalui media video online dankebutuhan informasi dengan pendekatan Uses and Gratification melalui media video online. Pengumpulan data dilakukan dengan menggunakan angket dan wawancara. Instrumen yang digunakan untuk mengumpulkan data dengan menggunakan angket dan wawancara terstruktur. Berdasarkan hasil penelitian, disimpulkan sebagai berikut. Pertama, mahasiswa Fakultas Sastra mampu melakukan penelusuran informasi melalui media video online dengan tahap yang runtut yaitu starting, chaining, browsing, monitoring, differentiatingdan extracting. Kedua, mahasiswa mampu memenuhi kebutuhan informasi dengan pendekatan Uses and Gratification mulai dari kebutuhan kognitif, kebutuhan afektif, kebutuhan integrasi pribadi, kebutuhan integrasi sosial dan kebutuhan pelarian.
\end{abstract}

\section{PENDAHULUAN}

Informasi merupakan hal yang penting dimanfaatkan oleh masyarakat luas demi memenuhi kebutuhannya masing-masing. Informasi yang dimaksud di sini dapat berperan sebagai sarana hiburan, komoditi, atau untuk mengerjakan tugas yang lain. Kebutuhan informasi setiap orang berbeda-beda tergantung dari status sosial, usia, pekerjaan dan lain sebagainya.

Untuk memenuhi kebutuhan informasinya, setiap orang akan melakukan penelusuran informasi dengan cara yang dianggap efektif dalam memenuhi kebutuhan akan informasinya. Penelusuran informasi dapat dilakukan secara konvensional dan digital. Penelusuran informasi secara konvensional dilakukan menggunakan kartu katalog, kamus, indeks, ensiklopedi maupun bibliografi. Sedangkan penelusuran informasi secara digital dilakukan menggunakan media digital atau elektronik seperti OPAC (Online Public Access Catalog), jurnal elektronik, search engine, dan informasi lain yang tersedia secara digital atau elektronik (Putra, Andajani, \& Istiqomah, 2018).

Perilaku pengguna internet di Indonesia termasuk aktif dalam penelusuran informasi. Hasil survey APJII 2016 alasan utama mengakses internet oleh warganet indonesia sebanyak 31,3 juta (25,3\%) untuk update informasi, sebanyak 27,6 juta (20,8\%) terkait pekerjaan, sebanyak 17,9 juta (13,5\%) mengisi waktu luang, sisanya untuk sosialisasi, terkait pendidikan, hiburan, bisnis dan berdagang. Informasi yang diakses oleh warganet sangat beraneka ragam mulai dari tekstual, gambar, hingga video. Banyak warganet yang mencari informasi dikarenakan beragamnya kanal-kanal penyedia informasi. Penelusur informasi dapat mengakses informasi dari berbagai macam perangkat mulai dari laptop, komputer, tablet, hingga gawai.

\footnotetext{
* Corresponding author.

E-mail addresses: master.peppy666@gmail.com (Fakhriza Palaivi), Idalestari_54@yahoo.com (Ida Lestari), taufiq.library@gmail.com (Taufiq Kurniawan)
}

ISSN : 2579-3802 (Online) - BIBLIOTIKA : Jurnal Kajian Perpustakaan dan Informasi is licensed under Creative Commons AttributionShareAlike 4.0 International License (http://creativecommons.org/licenses/BY/4.0/).

56 | BIBLIOTIKA : Jurnal Kajian Perpustakaan dan Informasi 
Pengguna media sosial dalam pencarian informasi konten video merupakan pihak yang paling aktif berkomunikasi untuk pemenuhan kebutuhannya. Hal tersebut sesuai dengan teori Uses and Gratifications yang diungkapkan oleh Elihu Katz pada tahun 1959, sebagai reaksi terhadap Bernard Berelson yang menyatakan bahwa penelitian komunikasi mengenai efek media massa sudah mati. Penelitian yang mulai hiduptentang usaha untuk menjawab pertanyaan "what do people do with media?". Teori Uses and Gratificationsdijelaskan bahwa pengguna harus aktif untuk menentukan media mana yang harus dipilih untuk memuaskan kebutuhannya.Teori ini lebih menekankan pada pendekatan manusiawi dalam melihat media massa.Artinya, manusia itumempunyai otonomi, wewenang untuk memperlakukan media.

Berkaitan dengan penelusuran informasi yang dilakukan oleh warganet, mahasiswa merupakan pihak yang paling sering melakukan aktifitas tersebut. Hal ini dikarenakan sebagian besar mahasiswa melakukan aktifitas tersebut untuk memenuhi tugas-tugas kuliah maupun yang lainnya. Peneliti tertarik untuk melakukan penelitian di Universitas Negeri Malang (UM) khususnya di Fakultas Sastra dengan harapan mampu menjelaskan aktifitas penelusuran informasi melalui media video online.

Penelitian sejenis yang berkaitan dengan perilaku penelusuran informasi melalui media video online adalah "Pemanfaatan Youtube di Kalangan Mahasiswa Mahasiswa IImu Komunikasi Fisip Universitas Sumatera Utarara Medan”yang ditulis Aritas Puica (2010). Hasil penelitian tersebut menunjukkan bahwa Youtube digunakan oleh kalangan mahasiswa Ilmu Komunikasi FISIP Universitas Sumatera Utara Medan untuk memperoleh informasi yang terkait dengan perkuliahan serta kebanyakan digunakan untuk mengunggah tugas perkuliahan.

Tujuan penelitian ini adalah untuk mengetahui perilaku penelusuran informasi dan kebutuhan informasi dengan memanfaatka media video online mahasiswa Fakultas Sastra Universitas Negeri Malang.

\section{METODE}

Jenis penelitian yang digunakan adalah deskriptif. Penelitian ini bertujuan untuk memperoleh data tentang perilaku penelusuran informasi pemanfaatan media video online oleh mahasiswa Fakultas Sastra Universitas Negeri Malang.

Populasi penelitian ini yaitu mahasiswa Fakultas Sastra Universitas Negeri Malang yang diharapkan mampu mewakili keseluruhan pengguna yang memanfaatkan media video online dalam menelusur informasi. Populasi yang diambil berdasarkan data akademik Fakultas Sastra tahun akademik 2017/2018 yang terdiri dari 4728 mahasiswa yang tersebar dalam 5 jurusan

Data yang diperoleh dari penelitian ini adalah data terkait masalah penelitian mengenai perilaku penelusuran informasi dan kebutuhan informasi media video online dengan pendekatan Uses and Gratification melalui pemanfaatan media video online mahasiswa Fakultas Sastra Universitas Negeri Malang.

Sumber data penelitian ini adalah hasil angket yang diisi oleh mahasiswa Fakultas Sastra Universitas Negeri Malang. Hasil angket untuk menjawab rumusan masalah terkait perilaku penelusuran informasi dan kebutuhan informasi dengan pendekatan Uses and Gratification melalui pemanfaatan media video online.

Pengumpulan data dilakukan terhadap mahasiswa yang menjadi sampel, yaitu mahasiswa Fakultas Sastra Universitas Negeri Malang. Agar data yang diperoleh dapat relevan dengan penelitian, penulis menggunakan teknik angket dan wawancara. Pengumpulan data dengan menggunakan angket dimaksudkan untuk mengetahui kebutuhan informasi dan kemampuan literasi informasi mahasiswa yang akan menjadi data primer. Data yang diperoleh dari hasil angket selanjutnya dianalisa dan dicatat dalam sebuah kolom pada tabel perolehan. Wawancara dilakukan oleh peneliti untuk mencari data tambahan atau data sekunder untuk memperkuat data primer.

Analisis data dilakukan setelah data terkumpul. Analisis data merupakan pengorganisasian secara jelas dan rinci yang menjadi kesimpulan ringkas untuk menghasilkan data. Terdapat beberapa langkah dalam analisis data yang harus dilakukan yaitu: (1) persiapan, (2) perhitungan, (3) tabulasi, dan (4) penyajian data. Berdasarkan langkah tersebut, analisis data dalam penelitian ini dapat diuraikan sebagai berikut. Pertama, kegiatan persiapan yaitu: (1) mengecek kelengkapan identitas sampel dan (2) mengecek kelengkapan data, yaitu dengan memeriksa isi instrumen yang bertujuan untuk melihat apakah data yang diperoleh sudah dijawab sesuai dengan petunjuk yang ada. Kedua, perhitungan. Pada tahap ini data hasil angket diinput kedalam program microsof excel untuk dihitung frekuensi dan persentasenya. Ketiga, kegitan tabulasi data dilakukan dengan cara: (1) pemberian kode untuk memudahkan proses analisis dan (2) mengubah data dalam bentuk tabel untuk mempermudah dalam melakukan paparan tentang kebutuhan informasi dan kemampuan literasi informasi mahasiswa. Keempat, penyajian data. Setelah data dari hasil angket disajikan dalam bentuk tabel untuk memudahkan dalam pengelompokkan, kemudian data dipaparkan dengan cara deskriptif sehingga dapat dengan mudah dipahami. 


\section{HASIL PENELITIAN}

Penelusuran informasi untuk memenuhi kebutuhan informasi yang diperlukan sangat beragam bentuk dan cara pemenuhannya. Pemenuhan kebutuhan informasi dapat dilakukan melalui offline antara lain buku, majalah atau bahan pustaka tercetak maupun melalui online atau melalui internet dengan menulusur website yang menyediakan informasi yang diperlukan yang berupa teks, gambar, audio, maupun video. Semua penelusuran memiliki cara penelusuran atau cara mencari informasi baik yang offline maupun online. Penelusuran secara online banyak diminati sekarang ini karena mudahnya aksesterutama bagi penelusur dari kalangan mahasiswa. Bentuk informasi yang sering diakses salah satunya adalah video karena dapat mencakup audio, gambar maupun teks. Mahasiswa pada umumnya dan mahasiswa Fakultas Sastra Universitas Negeri Malang khususnya sebagai penelusur yang sering mencari informasi secara online mengakses video untuk memenuhi kebutuhan informasi melalui media video online tentu memiliki pola penelusurannya masing-masing.

Penelusuran informasi melalui media video online meliputi Starting, Chaining, Browsing, Differentiating, Monitoring dan Extracting. Tahapan Starting selain menggunakan smartphone atau tablet mahasiswa dalam memulai penelusuran informasi juga menggunakan komputer atau laptop. Hal tersebut terjadi karena kemampuan untuk mengakses informasi melalui media video online sangat tinggi.

Tahapan Chaining dalam mengakses video sebagian besar mahasiswa sangat setuju untuk memanfaatkan internet. Pemanfaatan internet untuk mengakses video oleh mahasiswa baik yang menggunakan WIFI maupun paket data merupakan hal yang lumrah terjadi, karena tanpa adanya internet mereka tidak bisa mengakses video untuk mencari informasi secara online.

Tahapan Browsing terdiri dari fitur Search, Trending, Recommended, Watch It Again, Recently Uploaded. Sebagian besar mahasiswa sangat setuju dalam menelusur informasi di media video online menggunakan fitur Search. Fitur search pada media video online digunakan mahasiswa untuk menelusur informasi berupa video dengan memasukkan kata kunci yang berhubungan dengan informasi yang dibutuhkan atau yang diperlukan. Sebagian besar mahasiswa setuju dalam menelusur informasi di media video online menggunakan fitur Trending. Fitur ini merupakan salah satu cara menelusur informasi yang ada dalam media video online berdasarkan apa yang banyak diakses oleh penelusur lainnya pada website yang menyediakan video di suatu wilayah atau area yang dapat berupa negara tertentu. Sebagian besar mahasiswa setuju dalam menelusur informasi di media video online menggunakan fitur Recommended. Fitur ini akan menyajikan video-video yang berkaitan dengan video yang pernah mereka lihat sebelumnya. Sebagian besar mahasiswa setuju dalam menelusur informasi di media video online menggunakan fitur Watch It Again. Fitur ini memiliki fungsi untuk membuat video dimasukkan kedalam fitur Watch It Again agar dapat melihat video tersebut dilain waktu bila dibutuhkan kedepannya. Sebagian besar mahasiswa setuju dalam menelusur informasi di media video online menggunakan fitur Recently Uploaded. Fitur ini berfungsi untuk menampilkan video-video yang terbaru atau baru saja diunggah berdasarkan video yang pernah dilihatsebelumnya sehingga menarik untuk penelusur melihat informasi terbaru tersebut.

Tahapan Differentiating terdiri dari jumlah views, jumlah subscribers, pertimbangan pengunggah video, Verified Channel dan kemutakhiran video.Sebagian besar mahasiswa sangat setuju dalam menelusur informasi di media video online mempertimbangkan jumlah views. Jumlah views dalam video di media video online merupakan jumlah pengakses video tersebut setelah dipublikasi oleh pengunggah video. Sebagian besar mahasiswa tidak setuju dalam menelusur informasi di media video online mempertimbangkan jumlah subscribers. Jumlah subscriber adalah penelusur informasi yang mengikuti channel tersebut sehingga mereka akan mendapatkan informasi tentang apa yang telah diunggah oleh channel yang mereka subscribe.Sebagian besar mahasiswa setuju dalam menelusur informasi di media video online mempertimbangkan channel pengunggah. Channel pengunggah video adalah akun yang memberikan informasi tersebut melalui video di media video online. Sebagian besar mahasiswa setuju dalam menelusur informasi di media video online mempertimbangkan Verified Channel. Verified Channel merupakan akun yang mengunggah informasi dalam bentuk video di media video online yang telah diverifikasi oleh website media video online tersebut biasanya ditandai dengan tanda centang di sebelah nama akun tersebut. Sebagian besar mahasiswa setuju dalam menelusur informasi di media video online mempertimbangkan kemutakhiran video. Kemutakhiran informasi dalam media video online dapat dilihat dari kalom deskripsi yang terletak dibawah video tersebut akan tertulis kapan video tersebut dipublikasikan.

Tahapan Monitoring terdiri dari berlangganan saluran yang memberi informasi dan melihat video lain di Channel yang memberi informasi.Sebagian besar mahasiswa setuju dalam menelusur informasi di media video online mempertimbangkan berlangganan saluran yang memberi informasi. Berlangganan saluran yang memberi informasi akan mendapatkan informasi yang diposting oleh saluran yang dilanggan. Sebagian besar mahasiswa setuju dalam menelusur informasi di media video online mempertimbangkan 
video lain dari Channel yang menyediakan informasi. Channel yang menyediakan informasi mungkin saja telah mempublikasi video yang berisi informasi yang berkaitan tentang video yang mereka lihat sebelumnya.

Tahapan Extractingterdiri dari mempertimbangkan kolom deskripsi dan komentar. Sebagian besar mahasiswa setuju dalam menelusur informasi di media video online mempertimbangkan kolom deskripsi untuk memperdalam informasi di video yang dilihat. Kolom deskripsi dapat berisi tentang tanggal publikasi, jenis video maupun sumber informasi yang ada dalam video. Sebagian besar mahasiswa setuju dalam menelusur informasi di media video online mempertimbangkan kolom komentar untuk memperdalam informasi di video. Kolom komentar merupakan sarana bagi penelusur informasi untuk menyampaikan tanggapan mengenai informasi dalam video tersebut yang bisa saja menambah atau mengkoreksi informasi didalamnya.

Kebutuhan informasi mahasiswa Fakultas Sastra Universitas Negeri Malang dapat dibagi menjadi kebutuhan kognitif, kebutuhan afektif, kebutuhan integrasi pribadi, kebutuhan integrasi sosial dan kebutuhan pelarian. Kebutuhan kognitif terdiri dari penyelesaian tugas kuliah dan menambah pengetahuan. Sebagian besar mahasiswa setuju memanfaatkan informasi di media video online untuk menyeselesaikan tugas perkuliahan. Video dalam website penyedia layanan video online dapat pula membantu mahasiswa menyelesaikan tugas yang diberikan dalam perkuliahan. Sebagian besar mahasiswa sangat setuju memanfaatkan informasi di media video online untuk menambah pengetahuan. Menambah pengetahuan yang berbeda yang mungkin belum mereka ketahui.

Kebutuhan afektif terdiri dari tingkat kepercayaan dan dapat dipertangung jawabkan informasi di media video online. Sebagian besar mahasiswasangat setuju bahwa informasi di media video online terpercaya dan dapat dipertanggung jawabkan. Informasi yang diperlukan untuk memenuhi kebutuhan informasi perlu yang terpercaya dan dapat dipertanggung jawabkan.

Kebutuhan integrasi pribadi terdiri dari menambah pemahaman mengenai suatu bidang tertentu. Sebagian besar mahasiswa sangat setuju memanfaatkan media video online untuk menambah pemahaman mengenai suatu bidang tertentu. Bidang yang perlu untuk menambah pemahaman tidak selalu mengenai perkuliahan dapat juga bidang yang diminati atau yang disukai.

Kebutuhan integrasi sosial terdiri dari membagikan video yang telah dilihat. Sebagian besar mahasiswa tidak setuju membagikan video yang telah dilihat. Salah satu fitur untuk menyebar luaskan video di media video online adalah adanya fitur share didalamnya.

Kebutuhan pelarian terdiri dari mencari hiburan sangat tinggi. Sebagian besar mahasiswa sangat setuju mencari informasi di media video online untukhiburan Selain informasi yang dapat menunjang tugas dan pekerjaan didalam media video online terdapat juga hiburan didalamnya.

\section{PEMBAHASAN}

Tahapan awal penelusuran informasi, alat yang digunakan untuk menelusur informasi di media video online yang mereka gunakan seperti smarphone dalam mengakses informasi memiliki cara yang lebih mudah. Hal tersebut sesuai dengan pernyataan Heyes dalam Alia (2014) smartphone adalah cara yang lebih mudah dalam mengakses informasi dan berinteraksi dengan teman-teman kita melalui internet. Bagi sebagian besar orang, smartphone sudah menjadi kesatuan dari sifat mereka. Cara yang lebih mudah yang dimaksud adalah penelusuran informasi hanya mengetikkan kata kunci melalui media video online maka akan muncul hasil yang berhubungan dengan kata kunci yang mereka ketikkan.

Tahapan selanjutnya Chaining, penggunaan internet sebagai sarana penelusuran informasi sangat diminati karena dapat mengakses ke seluruh sumber, dapat menggabungkan beberapa sumber dan memiliki kemampuan multimedia. Hal tersebut sesuai dengan pernyataan Abdul Rahman Saleh (dalam Savitri 2016) internet digunakan oleh banyak orang karena menawarkan banyak manfaat, antara lain sepertidapat mengakses ke seluruh sumber-sumber informasi di dunia secara tidak terbatas danmempunyai fasilitas hyperlink yang memungkinkan kita menggabungkan informasi dari sumber yang satu dengan informasi dari sumber lain yang berada di dunia maya internet.

Tahapan Browsing mengenai penggunaan fitur Search sangat diminati oleh para penelusur karena dengan fitur ini mereka dapat mendapatkan hasil video yang relevan dengan kata kunci atau kueri yang mereka ketikkan. Hal tersebut sesuai dengan pernyataan Youtube Creators (2017) penelusuran di YouTube akan berusaha menampilkan hasil yang paling relevan berdasarkan kueri kata kunci. Video diberi peringkat berdasarkan banyak faktor, termasuk seberapa baik kecocokan judul, deskripsi, dan konten video dengan kueri penonton.Selanjutnya penggunaan fitur Trending tinggi dikarenakan fitur ini menyajikan video yang banyak diakses warganet, yang baru dan faktor lainnya. Hal tersebut sesuai dengan pernyataan Google Support (2017) diantara banyak video baru di YouTube pada hari tertentu, Trending hanya dapat menunjukkan sejumlah terbatas.Fitur Reccomended menyediakan informasi berupa video-video yang 
pernah ditonton sebelumnya atau memiliki topik yang serupa. Hal tersebut sesuai dengan pendapat Youtube Creators (2017) rekomendasi video adalah koleksi video yang dipersonalisasi oleh masing-masing penonton, yang tertarik untuk menonton lebih lanjut berdasarkan aktivitas sebelumnya. Fitur Watch It Again membuat daftar video yang akan ditonton di masa yang akan datang baik yang sudah pernah ditonton maupun belum di fitur "Tonton Nanti" hal tersebut sesuai dengan pernyataan Google Support (2017) dengan menambahkan video ke daftar putar "Tonton Nanti", sehingga dapat mengaksesnya dengan mudah kapan saja, baik untuk menontonnya kembali atau untuk pertama kalinya.Penggunaan fitur Recently Uploaded tinggi karena untuk menghindari masalah ingatan dan kebosanan dengan memperlajari hal baru yang ada di media video online hal ini sesuai dengan pendapat Torie Natalova (2017) mempelajari sesuatu yang baru menyebabkan otak membangun koneksi antar neuron, mengganti beberapa yang hilang seiring berjalannya waktu. Sering melakukan hal baru juga akan menumbuhkan pola pikir yang lebih berkembang, mendorong ketekutan dan ketahanan.

Tahapan Differentiating, penelusur dalam mencari informasi yang dibutuhkan karena banyak orang mengaksesnya yang mungkin saja bertentangan dengan keyakinan mereka sendiri. Pernyataan tersebut sesuai dengan pendapat Linda (2017) efek bandwagon adalah fenomena psikologis di mana orang melakukan sesuatu terutama karena orang lain melakukannya, terlepas dari keyakinan mereka sendiri, yang mungkin mereka abaikan atau timpa. Selanjutnya tentang jumlah subscribers hanya menunjukkan akun yang melanggan channel tersebut bukan kebenaran informasi yang diunggah didalamnya. Hal ini sesuai dengan pendapat Support Google (2017) bahwajumlah pengguna yang telah subscribe ke channel YouTube adalah orang yang mengikuti channel tertentu. Channel yang sudah Verified banyak dikases karena channel tersebut sudah mapan dalam menyediakan informasi dalam bentuk video. Hal tersebut sesuai dengan pernyataan Support Google (2017) bahwa jika terlihat tanda centang verifikasi $\square$ atau $\vartheta_{\text {di }}$ samping nama channel YouTube, berarti channel tersebut adalah milik kreator yang sudah mapan, atau merupakan channel resmi milik suatu brand, bisnis, atau organisasi.Pertimbangan kemutakhiran video dalam menelusur informasi oleh mahasiswa tinggi karena dalam penelusuran informasi tidak hanya melalui penelusuran offline seperti perpustakaan. Hal tersebut sesuai dengan pernyataan Prawati (2003) bahwa penyediaan atau pengadaan tidak sebatas tersedia di perpustakaan, tetapi harus mempertimbangkan beberapa aspek salah satunya kemutakhiran informasi.

Tahapan selanjutnya Monitoring, banyak mahasiswa berlangganan channel karena memiliki beberapa keuntungan yaitu mengikuti informasi yang dipublikasi channel tersebut. Hal tersebut sesuai dengan pernyataan Helianthusonfri (2016:168) secara umum ada tiga alasan mengapa orang-orang mau mengikuti sebuah channel Youtube. Tiga alasan tersebut antara lain Channel Youtube antara lain memberikan hiburan, informasi atau edukasi. Mahasiswa sebagian besar melihat video pada Channelyang sama,hal tersebut merupakan salah satu strategi penelusuran informasi, selain menghemat waktu juga memperoleh informasi yang relevan dengan video yang pernah dilihat sebelumnya. Hal tersebut sesuai dengan pendapat Purwono (2008:10) bahwa menelusur informasi di internet diperlukan karenainformasi yang tersedia menghemat waktu pencarian, sangat relevan, sangat banyak dan beraneka ragam

Tahapan yang terakhir yaitu Extracting, adanya kolom deskripsi dapat membuat mahasiswa ingin melihat video tersebut, mempelajari atau menemukan informasi yang dibutuhkan. Hal tersebut sesuai dengan pernyataan Youtube Creators (2017) bahwa bidang deskripsi sangat berguna untuk membantu penelusur informasi menemukan, mempelajari, dan memutuskan apakah mereka ingin menonton video anda atau tidak. Pertimbangan melihat kolom komentar dalam menelusur informasi tinggi. Kolom ini memfasilitasi penonton untuk berdiskusi mengenai informasi pada video yang mereka akses. Hal tersebut sesuai dengan pernyataan Youtube Creators (2017) percakapan di kalangan penonton pasti akan terjadi dengan atau tanpa keterlibatan Channeldi bagian komentar di YouTube.

Pemenuhan kebutuhan kognitif dalam penggunaan internet khususnya melalui media video online oleh mahasiswa untuk mengerjakan tugas karena dapat melakukan komunikasi secara singkron, interaktif dan sebagai media massa. Hal tersebut sesuai dengan pernyataan Hardjito (2002) bahwa internet memang dapat digunakan dalam mendukung perkuliahan di perguruan tinggi karena memiliki karakteristik yang khas seperti interaktif. Internet khususnya media video online dimanfaatkan untuk menambah pengetahuan karena berasal dari seluruh dunia, selalu diperbarui dan berbagai macam bentuk. Hal tersebut sesuai dengan pernyataan Krentnian (2012) bahwa internet merupakan mesin mencari segala informasi yang dibutuhkan oleh banyak kalangan dalam memperluas cakrawala dan akses informasi segala penjuru dunia.

Pemenuhan kebutuhan afektif untuk tingkat kepercayaan informasi pada media video onlinetinggikarena mudahnya informasi yang ada pada media video online untuk dicerna. Hal tersebut sesuai dengan pernyataan Anindyaputri (2017) setiap orang punya kecenderungan alami untuk memercayai informasi yang mudah dicerna.

60 | BIBLIOTIKA : Jurnal Kajian Perpustakaan dan Informasi 
Pemenuhan kebutuhan integrasi pribadi, informasi di internet sangatlah banyak dan beragam untuk menambah pemahaman begitu juga pada media video online. Hal tersebut sesuai dengan pernyataan Krentnian (2012) bahwa banyaknya informasi dan ilmu pengetahuan yang terdapat pada dunia maya atau internet, maka akan menjadi media untuk meningkatkan pengetahuan dan pemahaman bagi penggunanya yang aktif mengikuti sebuah situs ilmu pengetahuan dan disiplin ilmu yang dipublikasikan melalui situs resmi di internet.

Pemenuhan kebuthan integrasi sosial, perihal mahasiswa tidak mau membagikan informasi yang mereka miliki bisa diartikan sebagai memenuhi kebutuhan mereka terlebih dahulu. Hal tersebut sesuai dengan pernyataan Deuter (dalam metrotvnews 2015) bahwa menempatkan diri anda lebih dahulu bukanlah kualitas negatif. Itu adalah tugas anda untuk mengurus diri sendiri dan mendapatkan apa yang anda butuhkan.

Pemenuhan kebutuhan pelarian, kebanyakan penelusur informasi di media video onlineuntuk mencari hiburan. Hal tersebut didukung dengan pernyataan Akbar (2005:10) Internet adalah sumber informasi, alat komunikasi serta alat hiburan.

\section{SIMPULAN DAN SARAN}

Mahasiswa dalam menelusur informasi melalui media video online telah mampu dengan runtut melakukan tahapan-tahapannya mulai dari Starting, Chaining, Browsing, Differentiating, Monitoring, dan Extracting. Tahapan tersebut dilaksanakan mahasiswa untuk memenuhi kebutuhan informasi yang dapat di kelompokkan menjadi kebutuhan kognitif, afektif, integrasi pribadi, integrasi sosial dan kebutuhan pelarian. Mahasiswa dalam memenuhi kebutuhan informasi dapat memilah dan memilih informasi seperti apa yang mereka perlukan dan dapat dimanfaatkan dengan cukup maksimal.

Mahasiswa hendaknya mampu memanfaatkan segala fitur yang ada dalam internet khususnya pada media video online agar dapat memperoleh informasi yang relevan dan sesuai dengan kebutuhan informasinya. Mahasiswa juga seharusnya mampu membuat skala prioritas mengenai informasi seperti apa yang mereka butuhkan. Skala prioritas mengenai kebutuhan informasi akan membantu mahasiswa untuk menentukan informasi apa yang segera dipenuhi.

\section{DAFTAR RUJUKAN}

Akbar Ali. (2005). Menguasai Internet Plus Pembuatan Web. Bandung: M2S.

Alia, Sarifah Siti, dkk (2014). Studi: Pengguna Cek Smartphone 1.500 Kali Sehari Pengguna mengaku merasa hampa tanpa gadget. (online) (http://teknologi.news.viva.co.id/news/read/545999-studi-pengguna-ceksmartphone-1-500-kali-sehari). Diakses pada 13 April 2018.

Anindyaputri, Irene. (2017). Jangan Mau Ditipu! Ini Alasan Orang Mudah Percaya Berita Hoax.(online) (https://hellosehat.com/hidup-sehat/fakta-unik/mudah-percaya-berita-hoax/) Diakses pada 15 April 2018.

Batley, Sue. (2007). Information Architecture for Information Professionals. England: Chandos Publishing.

Creators, Youtube. (2017). Pelajaran: Menulis deskripsi cerdas. (online) (https://creatoracademy.youtube.com/page/lesson/descriptions?hl=id\#strategies-zippy-link-2) Diakses pada 14 April 2018.

Creators, Youtube. (2017). Pelajaran: Penelusuran dan penemuan di YouTube YouTube.(online)https://creatoracademy.youtube.com/page/lesson/discovery?hl=id\#strategieszippy-link-1). Diakses pada 13 April 2018.

Creators, Youtube. (2017). Pelajaran: Terhubung dengan komunitas Anda.(online)(https://creatoracademy.youtube.com/page/lesson/inviteconversation?hl=id\#strategies-zippy-link-1) Diakses pada 14 April 2018.

Hardjito. (2002). Internet untuk Pembelajaran. Jurnal Teknodik No. 10 tahun 2002

Helianthusonfri, Jefferly. (2016). YouTube Marketing. Jakarta. Elex Media Komputindo

Kasiram, M. (2008). Metodologi Penelitian Kualitatif-Kuantitatif. Malang: UIN Malang.

Krentnian, Zulkarnaen. (2012). Internet Cerdas : Dapat Banyak Informasi Dan Menambah Ilmu Pengetahuan. 
(online) (http://internetcerdasindonesia.org/artikel-internet-cerdas/internet-cerdas-dapat-banyakinformasi-dan-menambah-ilmu-pengetahuan) Diakses pada 15 April 2018.

Linda. (2017). The Bandwagon Effect :Are we going to think for ourselves?.(online)(https://www.psychologytoday.com/us/blog/stronger-the-brokenplaces/201708/the-bandwagon-effect) Diakses pada 14 April 2018.

Metrotvnews. (2015). Ternyata Ada Sisi Baik dari Sifat Egois.(online)(http://news.metrotvnews.com/read/2015/03/14/371233/ternyata-ada-sisi-baik-darisifat-egois) Diakses pada 15 April 2018.

Purwono. (2008) . Strategi penelusuran informasi melalui Internet. dalam Seminar sehari tentang "Strategi Penelusuran Informasi di Internetyang diselenggarakan oleh Himpunan mahasiswa Jurusan Ilmu Perpustakaan Fakultas Adab dan Humaniora Universitas Islam, Jurusan Ilmu Perpustakaan Fakultas Adab dan Humaniora Universitas Islam Negeri Syarif Hidayatullah, Jakarta. (Indonesia), April 30, 2008. (tidak dipublikasikan).

Putra, D. A., Andajani, K., \& Istiqomah, Z. (2018). Implementasi Preservasi Digital Koleksi Karya Ilmiah Di Perpustakaan Maulana Malik Inbrahim Malang. Bibliotika: Jurnal Kajian Perpustakaan Dan Informasi, 1(2), 28-33.

Sianipar, Aritas Puica. (2010). Pemanfaatan Youtube di Kalangan Mahasiswa (Studi Penggunaan Youtube di Kalangan Mahasiswa IImu Komunikasi FISIP USU Medan dengan Pendekatan Uses and Gratification)(online) (https://jurnal.usu.ac.id/flow/article/view/9930) Diakses pada 16 November 2018.

Support, Google. (2017). Jumlah $\quad$ subscriber: (online) (https://support.google.com/youtube/answer/6051134?hl=id) Diakses pada 14 April 2018.

Support, Google. (2017). Trending di YouTube. (online) (https://support.google.com/youtube/answer/7239739?hl=id). Diakses pada 14 April 2018. 